\title{
MAPPING POLITICAL THEORY USING BIBLIOMETRIC ANALYSIS
}

\author{
Muhammad Syaifuddin, Suswanta, Misran dan Syamsul Bahri Abd. Rasyid \\ Department of Master of Government Affairs and Administration, Universitas Muhammadiyah Yogyakarta \\ E-mail: Syaifuddinm95@gmail.com
}

\begin{abstract}
The purpose of this study is to determine the development of the study of political theory. This research is very important to be studied to see the tendency of previous researchers in studying political theory. The method used in this research is descriptive qualitative. In this study, the data used is data that has been downloaded from the Scopus database with some limitations to limit and be more specific on the results of the discussion. After the documents to be reviewed and analyzed bibliographically using VOSViewer and NVivo 12 Plus software, the data is exported in .CSV and .RIS formats. the findings in this study can map the study of political theory and provide an overview of the dominant topics being discussed so as to bring up newness in further research.
\end{abstract}

Keywords: Political Theory; Bibliometric; Mapping of concept

ABSTRACT. Tujuan penelitian ini untuk mengetahui perkembangan kajian tentang teori politik. penelitian ini sangat penting untuk dikaji untuk melihat kecenderungan peneliti sebelumya dalam mengkaji tentang teori politik. metode yang digunakan dalam penelitian ini kualitatif deskriptif. Dalam penelitian ini, data yang digunakan adalah data yang telah diunduh dari database Scopus dengan beberapa batasan untuk membatasi dan lebih spesifik pada hasil pembahasan. Setelah dokumen yang akan direview dan dianalisis bibliografi menggunakan software VOSViewer dan NVivo 12 Plus, data tersebut diekspor dalam format .CSV dan .RIS. temuan dalam penelitian ini dapat memetakan kajian teori politik dan memberikan gambaran tentang topik-topik dominan yang sedang dibahas sehingga memunculkan kebaruan dalam pada penelitian selanjutnya.

Keywords: Political theory; Bibliometric; Mapping of concept

\section{INTRODUCTION}

In terms of terminology, political science is the study of the art of government, public interaction, compromise, consensus, and the power and distribution of resources in public affairs (Winarno, 2013). In the philosophy of science, a scientific discipline is likely to have the same object of study as other sciences but has differences in its form (Syafiie, 2017). Likewise, political science has adopted many other social sciences (material objects). However, political science has a specificity in the definition of power, which Roskin (2020) is interpreted as the vertical hegemony of political actors over other actors.

In recent decades, many studies have explored the history of political science (Craig, 2020). Furthermore, Hood, King, and Peele (2014) describe how the development of politics at the University of Oxford, where the book examines institutions, plantations, funding, research, and curricula that are organized into broader intellectual and institutional development.

Meanwhile, experts who are members of the International Political Science Association have divided political science disciplines into more detailed sub-disciplines, namely; political science, political institutions, political behavior, comparative politics, international relations, political theory, administration and public policy, political economy, and political methodology (Nur, 2014). The scope of concepts discussed in political theory is: society, social class, state, power, sovereignty, rights and obligations, independence, state institutions, social change, political development, and modernization (Sitepu, 2012).

There are various theories in political science, for example, the political view of Niccolo Machiavelli, Jean Bodin, John Locke, Baron de Montesquieu, Robert Nozick (Haryanti and Pujilestari, 2019), to new approaches such as feminism, as well as loan ideas such as isolationism which are borrowed from journalistic language (Nur, 2014). These political theories are political theories born from the development process of political science thinking, namely; traditionalism, behavioralism, and postbehavioralism, which Budi Winarno calls a school of political science (Winarno, 2013).

This paper aims to describe the map of the development of political theory research globally, which is elaboratedusing the VOSviewerand NVivo 12 plus software. The documents reviewed are documents indexed in the Scopus database. The data processing in VOSviewer software is one of the research analysis techniques used to assess a researcher's impact (individual), research group, institution, country, or journal. This analysis is considered essential because it provides insights far beyond the scope of the journal (Ibraín Enrique Corrales-Reyes, Juan José ReyesPérez 2016; Jain et al. 2015; Krauskopf 2018; PerianesRodriguez, Waltman, and van Eck 2016; Restrepo and Willett 2017).

Furthermore, the authors also conducted an analysis using NVivo 12 plus software by categorizing 
themes related to "theory of political science," as well as relationships, mapping, and dominant topics in the map of research development on "theory of political science." The difference between this paper and previous research is in the data processing and analysis tools. This article uses VOSviewer software and is supported by NVivo 12 plus to strengthen the research results.

\section{METHODS}

This research uses qualitative methods with literature study. Qualitative research prioritizes extracting, discovering, reading, explaining, and conveying the explicit and tangible meaning or symbols of data from the data collected. Meanwhile, according to Danandjaja (in Sari, 2020), library research is a systematic scientific bibliographic analysis method, including collecting bibliographic materials related to research objectives, collection techniques with the literature method, and organizing and presenting data. So, it can be concluded that qualitative research methods with literature study techniques are data collection techniques based on finding written data such as notes, books, papers or articles, journals, and so on (Wicaksono et al. 2020). In bibliometric studies, data can be obtained from a primary, secondary, or tertiary journal covering a certain period and analyzed from various angles to determine the institution's distribution of articles, authorship patterns, citation patterns, and article length. Distribution of items, breakdown of articles by topic, and many other bibliographic attributes (Panda, Maharana, and Chhatar 2013).

This study aims to determine the development of research on political theory studies from 2016 to 2020 so that the authors set a year limit for documents taken, namely 2016 to 2020 . This year's limitation is to see the study of political theory in the last year. Five years. The source of this research data is from the Scopus database. Then the data is stored in RIS format for further processing using VOSviewer software, in Figure 1. The flow and stages of data collection and processing describe how researchers carry out the data collection process to data processing.

The authors chose Scopus as the database in data collection in this study (Hakim, 2020). Scopus is a database containing citations and abstracts monitored by experts in their fields, and in determining quality, documents uploaded to Scopus must go through peer review. According to the author, the publication journals in Scopus are quality worthy of being used as a source of data in this research. Several previous studies have defined Scopus. Scopus is a database containing tens of millions of Elsevier's scientific literature (Saleh and Sumarni 2016).

After the data collection process through Scopus, the data is processed through the software VOSviewer. VOSviewer itself is a data science processing software that has an output on Bibliometric Maps. The difference between VOSviewer and software equally bibliometric mapping is that VOSviewer pays special attention to the graphical representation of the bibliometric map.

Table 1. List of keywords selected in data collection in Scopus on the "political theory."

\begin{tabular}{rlrl}
\hline & & Filter by keywords \\
\hline 1 & Politics & 24 & Theoretical model \\
2 & Theoretical study & 25 & Capitalism \\
3 & Political science & 26 & Citizenship \\
4 & Political theory & 27 & Nationalism \\
5 & Social theory & 28 & Democratic theory \\
6 & Science & 29 & Social behavior \\
7 & Philosophy & 30 & Development \\
8 & Methodology & 31 & Political ideology \\
9 & Critical theory & 32 & Attitude \\
10 & Ideology & 33 & Marx \\
11 & History & 34 & Civil society \\
12 & Theory & 35 & Policy \\
13 & Government & 36 & Political psychology \\
14 & Knowledge & 37 & Social science \\
15 & Public policy & 38 & Colonialism \\
16 & Neoliberalism & 39 & Comparative study \\
17 & Feminism & 40 & Political ecology \\
18 & Epistemology & 41 & Political system \\
19 & Governance & 42 & Feminist theory \\
20 & Sociology theory & 43 & Geopolitics \\
21 & Marxism & 44 & Interdisciplinarity \\
22 & Political participation & 45 & Organization \\
\hline & Research & Political discourse \\
\hline
\end{tabular}

Source: by Authors

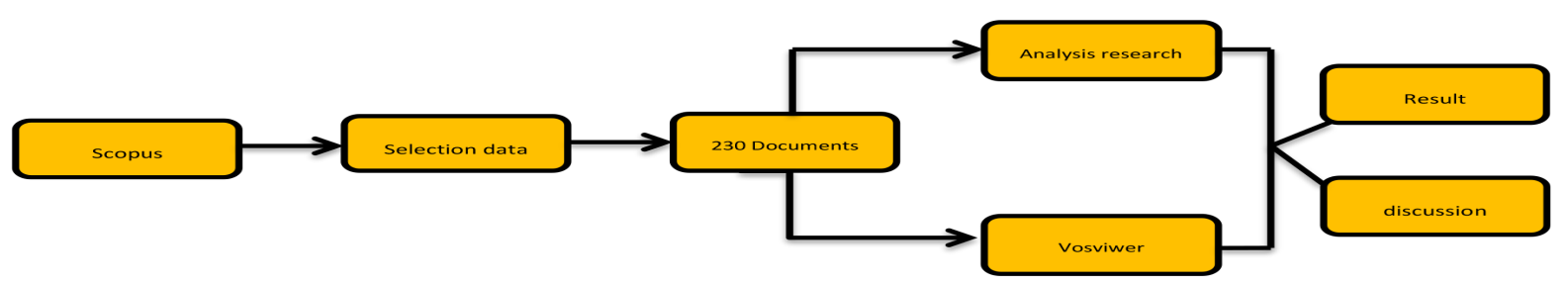

Figure 1. Data retrieval flow chart

Source: by authors 
Based on the table, it can be seen that the keywords used explicitly in the search for political science theory in the Scopus database.

\section{RESULT AND DISCUSSION}

\section{Document Type and Number of Publication}

In this study, researchers searched and analyzed data from the Scopus database (www.scopus.com) on "Political Theory" using several keywords. Keywords can be seen in table 1 above. Data were taken with a period from 2016-2020. The data search results found 230 research documents divided into two types of documents: articles and review articles. Article documents are 210 documents (91\%), and review articles documents are ten documents $(9 \%)$.
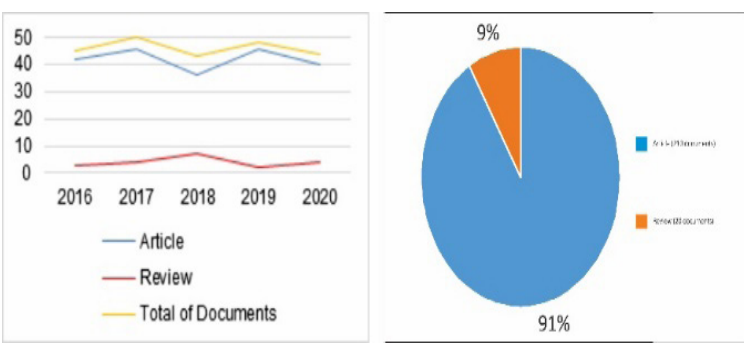

Source: Analysis Research on www.scopus.com

Figure 2. Document type and number of publication

In Figure 2 and Table 2, it can be found that research on the "Political Theory" in the last five years has not experienced much change, either a significant decrease or increase. In 2018 study on "Political Theory" on the type of article decreased from the previous year. The type of document review experienced an increase from 2017 and became the most in the last five years.

Table 2. Document type and number of publications

\begin{tabular}{ccccc}
\hline No & Year & Article & Review & Total \\
\hline 1 & 2020 & 42 & 3 & 45 \\
2 & 2019 & 46 & 4 & 50 \\
3 & 2018 & 36 & 7 & 43 \\
4 & 2017 & 46 & 2 & 48 \\
5 & 2016 & 40 & 4 & 44 \\
Total & & 210 & 20 & 230 \\
\hline
\end{tabular}

Source: by author

\section{Source of Publication}

Based on the results of the analysis of research on the Scopus database (www.scopus.com) about "Political Theory" in 2016-2020, (Figure 3) shows a graphic of the publication of each source, some have increased, some have even decreased. Not all sources publish "Theory of Political Science" every year.

The most published document data source is the British Journal of Sociology with several 15 documents, but in 2020 the British Journal of
Sociology did not find any publications on this source. Then in second and third place, Politics and The Life Science and the Swiss Political Science Review in 2016-2020 published six documents on "Theory of Political Science." Next, Sustainability Switzerland published five papers, and Sage Open posted four documents (Table 3 ).

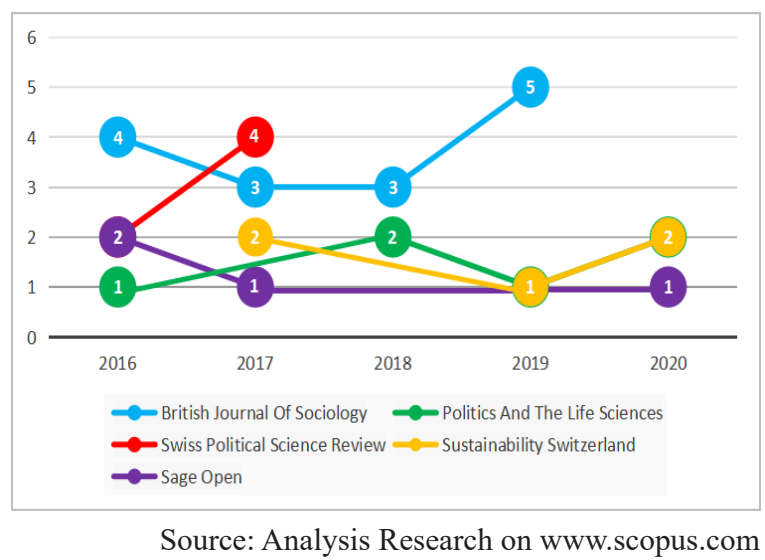

Figure 3. Publication Sources from "Political Theory"

Table 3. Source of document publication per year

\begin{tabular}{|c|c|c|c|c|c|c|}
\hline \multirow{2}{*}{ Source } & \multicolumn{5}{|c|}{ Document per year by source } & \multirow{2}{*}{ Total } \\
\hline & 2016 & 2017 & 2018 & 2019 & 2020 & \\
\hline $\begin{array}{l}\text { British Journal } \\
\text { Of Sociology }\end{array}$ & 4 & 3 & 3 & 5 & 0 & 15 \\
\hline $\begin{array}{l}\text { Politics And The } \\
\text { Life Sciences }\end{array}$ & 1 & 0 & 2 & 1 & 2 & 6 \\
\hline $\begin{array}{l}\text { Swiss Political } \\
\text { Science Review }\end{array}$ & 2 & 4 & 0 & 0 & 0 & 6 \\
\hline $\begin{array}{l}\text { Sustainability } \\
\text { Switzerland }\end{array}$ & 0 & 2 & 0 & 1 & 2 & 5 \\
\hline Sage Open & 2 & 1 & 0 & 0 & 1 & 4 \\
\hline
\end{tabular}

\section{Publication Based on Authors}

In (Figure 4) it can be seen that each researcher has almost the same number of publications on "Political Theory" from 2016-2020. Baum, Carreira da Silva, Chettimparamb, Rosenberg are in the top ranking with two documents published. Adamson, Aguilar, Albertsen, Anduiza, Ang, Asenbaum have each publication of 1 form, which only has a difference of 1 paper with four previous researchers.

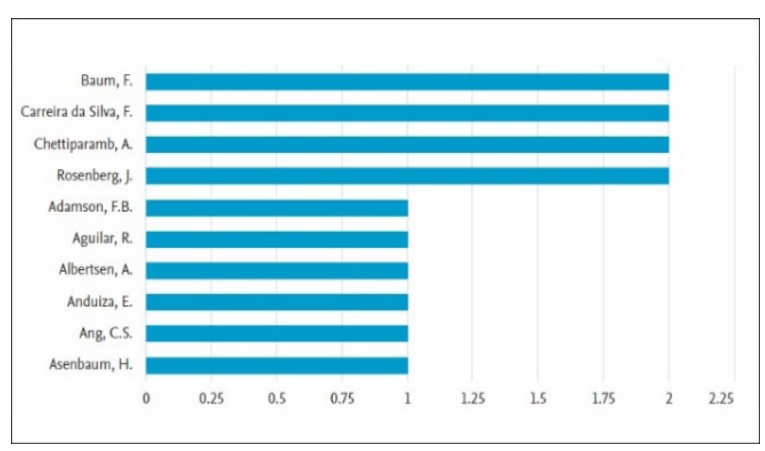

Source: Analysis Research on www.Scopus.com

Figure 4. Number of publication based on authors 


\section{Countries/Territories with the Most Publicants}

Research on the "Theory of Political Science" is carried out by many countries. From the search results on the Scopus database (www.Scopus.com) 2016 to 2020 with a limited research year, it can be found that the top 10 countries publish "Political Theory" (Figure 5).

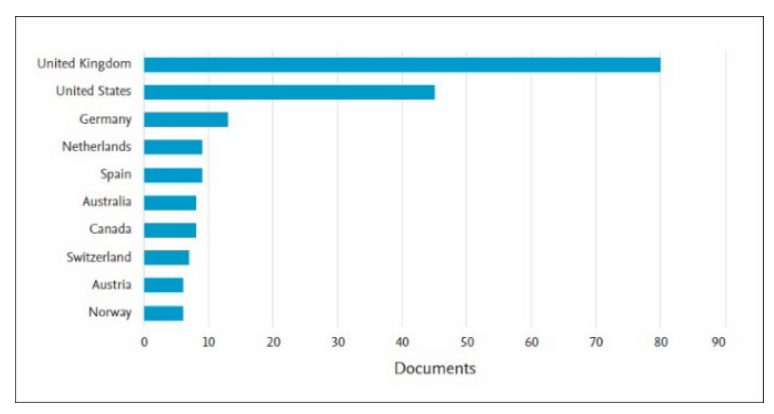

Source: Analysis Research on www.Scopus.com

Figure 5. Countries/Territories with the most publications

The United Kingdom is the country with the highest number of publications of 80 documents. In second place is the United States, with some publications of 45 papers. Then Germany with 13 papers. After that, Netherlands and Spain (9 papers), Australia and Canada (8 papers), Switzerland (7 papers), Austria and Norway (6 papers) (Table 4$)$.

Tabel 4. List of countries and the number of published documents in the theory of political science in 20162020

\begin{tabular}{lc}
\hline \multicolumn{1}{c}{ Country } & Number of Publication \\
\hline United Kingdom & 80 \\
United States & 45 \\
Germany & 13 \\
Netherlands & 9 \\
Spain & 9 \\
Australia & 8 \\
Canada & 8 \\
Switzerland & 7 \\
Austria & 6 \\
Norway & 6 \\
\hline
\end{tabular}

Source : by Author

\section{Publication of Documents by Affiliation}

Based on the results of the analysis from a search on the Scopus database (www.Scopus.com), it can be found that the number of document publications on "Political Theory" from 2016 to 2020 mainly was published by the University of Oxford, followed by the University of Cambridge. London School of Economics and Political Science, University College London and University of Sussex (Figure 6.).

From (Figure 6.), we can see the University of Oxford became the affiliate that published the most research documents on "Political Theory" with a total of 8 papers. Meanwhile, the University of Cambridge became the second largest with seven articles, followed by the London School of Economics and Political Science with six documents: the University College London and the University of Sussex with four papers.

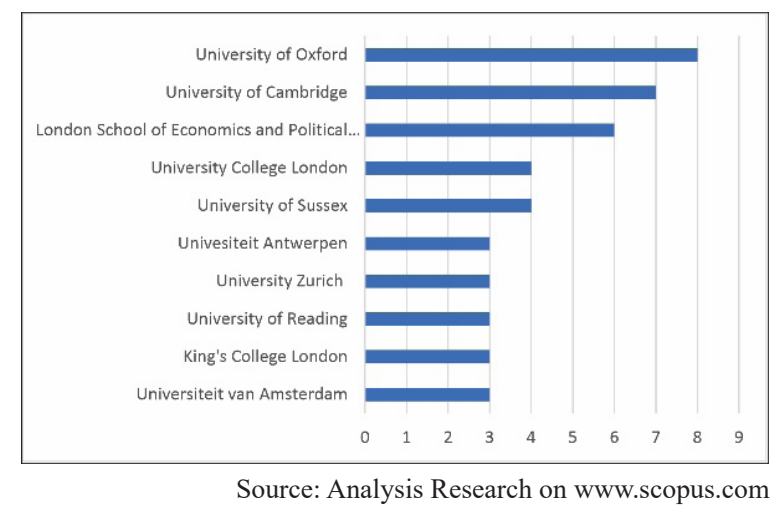

Figure 6. Number of document publications by affiliation

Visualization Networking Based on Keywords

Bibliometric analysis was performed by creating a network visualization based on keywords, country, and title and abstract using VOSViewer software to determine the bibliometric network consisting of nodes and edges (Figure 7), (Figure 8), (Figure 9). The nodes represented by circles can be publications, journals, researchers, or keywords (van Eck et al. 2010; Eck and Waltman 2014, 2016)we use innovative full-text citation analysis along with supervised topic modeling and network-analysis algorithms to enhance classical bibliometric analysis and publication/author/ venue ranking. By utilizing citation contexts extracted from a large number of full-text publications, each citation or publication is represented by a probability distribution over a set of predefined topics, where each topic is labeled by an author-contributed keyword. We then used publication/citation topic distribution to generate a citation graph with vertex prior and edge transitioning probability distributions. The publication importance score for each given topic is calculated by PageRank with edge and vertex prior distributions. To evaluate this work, we sampled 104 topics (labeled with keywords. Meanwhile, Edge indicates a relationship between two nodes, and the strength of the relationship is represented by distance. The closer the distance between the nodes of the nodes, other showed a high correlation between nodes (Aribowo, 2019).

Mapping and clustering are contemporary, complementing each other. Mapping can be used to obtain a detailed description of a bibliometric network (Waltman, van Eck, and Noyons, 2010). For the cluster itself, it has the aim of gaining insight or an overview of bibliometric grouping (Aribowo 2019a). In the visualization shown in Figure 7, each circle represents a keyword or term that frequently occurs, taken from the title and abstract of the document. Each process's size indicates the number of publications with a relationship with the word, 
either in the title or in the paper's abstract. The bigger the circle's size, the greater the number of articles relevant to that keyword or term. The terms that are close to each other in visualization, for example, the relation between Social Theory and Epistemology in the green circle on the left, are more intimate than the connection between Social Theory and Ethnography.

From the analysis, it was found that from the metadata of 230 documents, with the number of keywords that appeared three times, it was found that 66 keywords from 977 available keywords resulted in eight clusters (Table 5) (5 dominant clusters, three minority clusters), each of which each can be identified based on its color classification.

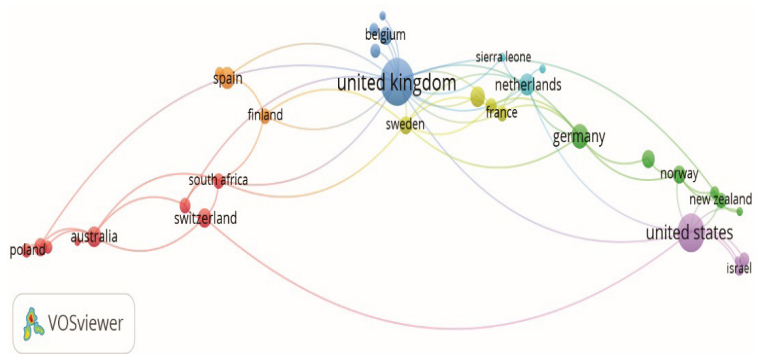

Source: by Authors use VOSViewer

Figure 8. Mapping and clustering of 230 documents by country in the theory Of Political Theory In 2016-2020
Table 5. The division of clusters and their items in the visualization based on keywords

\begin{tabular}{|c|c|}
\hline $\begin{array}{l}\text { Cluster } 1 \text { (Red) } \\
\text { (12 items) }\end{array}$ & $\begin{array}{l}\text { Crisis, ecology, gender, governance, } \\
\text { institutional change, institutions, liberalism, } \\
\text { nationalism, neoliberalism, political ideology, } \\
\text { religion, sustainability. }\end{array}$ \\
\hline $\begin{array}{l}\text { Cluster } 2 \text { (Geen) } \\
\text { (12 items) }\end{array}$ & $\begin{array}{l}\text { Development, epistemology, } \\
\text { ethnography,metodhology, political ecology, } \\
\text { science, social science, social theory, theory, } \\
\text { vulnerability. }\end{array}$ \\
\hline $\begin{array}{l}\text { Cluster } 3 \text { dark } \\
\text { blu ( } 9 \text { items) }\end{array}$ & $\begin{array}{l}\text { Citizenship, colonialism, democratic theory, } \\
\text { diversity, feminist theory, identity, ideology, } \\
\text { migration, political participation. }\end{array}$ \\
\hline $\begin{array}{l}\text { Cluster } 4 \\
\text { (Yellow) (8 } \\
\text { items) }\end{array}$ & $\begin{array}{l}\text { Capitalism, conspiracy theory, democracy, } \\
\text { interdisciplinary, international relations, } \\
\text { political psychology, populism, power. }\end{array}$ \\
\hline $\begin{array}{l}\text { Cluster } 5 \\
\text { (Purple) }(8 \\
\text { items) }\end{array}$ & $\begin{array}{l}\text { Area studies, comparative politics, } \\
\text { humanities, political economy, political } \\
\text { science, social sciences, sociology theory, } \\
\text { sociology. }\end{array}$ \\
\hline $\begin{array}{l}\text { Cluster } 6 \text { (light } \\
\text { blue) ( } 7 \text { items) }\end{array}$ & $\begin{array}{l}\text { Activism, civil society, ethics, materiality, } \\
\text { political philosophy, political theory, politics }\end{array}$ \\
\hline $\begin{array}{l}\text { Cluster } 7 \\
\text { (orange) (4 } \\
\text { items) }\end{array}$ & $\begin{array}{l}\text { Conflict, critical theory, intellectual history, } \\
\text { peace }\end{array}$ \\
\hline $\begin{array}{l}\text { Cluster } 8 \\
\text { (Brown) }(3 \\
\text { items) }\end{array}$ & $\begin{array}{l}\text { Government, legitimacy, public policy light } \\
\text { blue, orange Brown }\end{array}$ \\
\hline
\end{tabular}

Source: by Author use VOSviewer

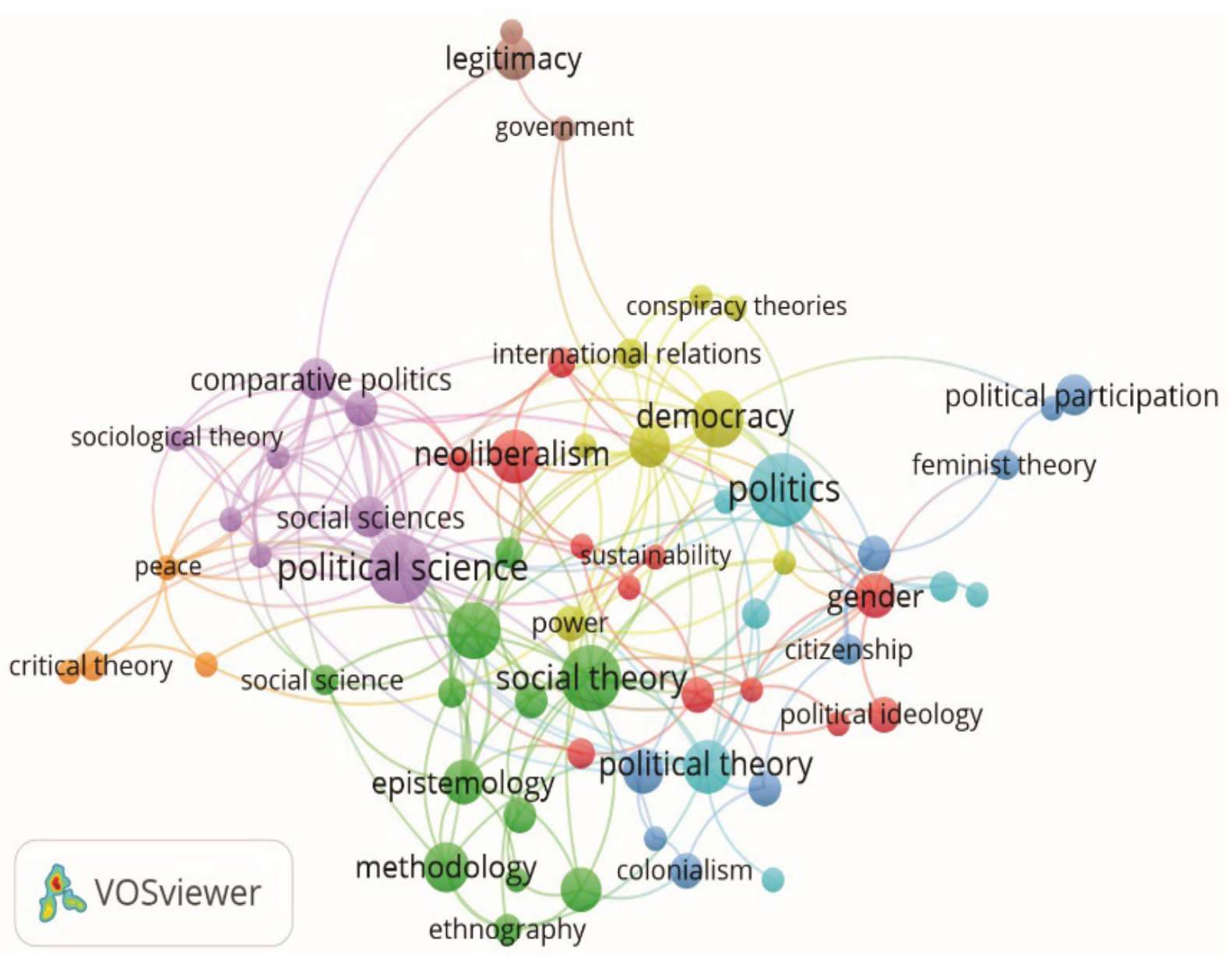




\section{Visualization Networking Based on Countries}

From the results of processing 230 documents to determine the country of origin of each paper's authors in "Political Theory" in 2016-2020, 33 items were found with 7 clusters (Table 6).

Table 6. The division of clusters and their items in the visualization based on keywords

\begin{tabular}{ll}
\hline $\begin{array}{l}\text { Cluster 1 (8 } \\
\text { items) }\end{array}$ & $\begin{array}{l}\text { Australia, Brunei Darussalam, Czech Republic, } \\
\text { Poland, Portugal, Russian Federation, South } \\
\text { Africa, Switzerland. }\end{array}$ \\
$\begin{array}{l}\text { Cluster 2 (6 } \\
\text { items) }\end{array}$ & $\begin{array}{l}\text { Argentina, Denmark, Germany, India, New } \\
\text { Zealand, Norway. }\end{array}$ \\
items) \\
$\begin{array}{l}\text { Cluster 4 (4 } \\
\text { items) }\end{array}$ & $\begin{array}{l}\text { Kelgium, Hungary, Ireland, Lebanon, United } \\
\text { Cluster 5 (4 }\end{array}$ \\
$\begin{array}{l}\text { Canada, France, Italy, Sweden. } \\
\text { Cluster 6 (3 }\end{array}$ & Brael, Mexico, Singapore, United States. \\
items) \\
$\begin{array}{l}\text { Cluster 7 (3 } \\
\text { items) }\end{array}$
\end{tabular}

Source: by Author use VOSviewer

\section{Inter-Topic Networking in Theory of Political} Science in 2016-2020

Researchers also conducted mapping and clustering analysis of the relationship between the topics discussed in "Theory of Political Science." From the results of this analysis (Figure 9), the topic theory most often appears in the "theory of political science" from 2016 to 2020, and the color label shows that there are 4 clusters of topics discussed in the "theory of political science."
With the number of topics that appeared ten times, we found 108 out of 6694 themes and resulted in 4 clusters with 76 items in them (Table 7).

Table 7. The division of clusters and their items in the visualization is based on the title in "Theory of Political Science," which was published in 2016-2020

\begin{tabular}{|c|c|}
\hline $\begin{array}{l}\text { Cluster } 1 \\
(29 \text { items) }\end{array}$ & $\begin{array}{l}\text { Analysis, argument, case, case study, condition, } \\
\text { country, data, debate, effect, evidence, factor, gap, } \\
\text { gender, government, ideology, implication, influence, } \\
\text { legitimacy, literature, model, person, policy, process, } \\
\text { research, response, role, study, theory, value. }\end{array}$ \\
\hline $\begin{array}{l}\text { Cluster } 2 \\
(26 \text { items) }\end{array}$ & $\begin{array}{l}\text { Approach, author, building, concept, contrast, } \\
\text { critique, discipline, economic, fact, focus, history, } \\
\text { idea, interest, opportunity, perspective, philosophy, } \\
\text { political science, problem, relation, science, social } \\
\text { science, society, sociology, state, structure, world. }\end{array}$ \\
\hline $\begin{array}{l}\text { Cluster } 3 \\
\text { (13 items) }\end{array}$ & $\begin{array}{l}\text { Community, democracy, development, discourse, } \\
\text { education, future research, impact, knowledge, } \\
\text { politic, power, practice, relationship, review. }\end{array}$ \\
\hline $\begin{array}{l}\text { Cluster } 4 \\
(10 \text { items })\end{array}$ & $\begin{array}{l}\text { Challenge, contribution, field, Framework, importance, } \\
\text { issue, political theory, possibility, scholar, work. }\end{array}$ \\
\hline
\end{tabular}

Source: by Author

VOSViewer uses the primary color red-bluegreen (RGB) in every visualization it produces. Density visualization of the results shown in Figure 10 explains that the node adjacent to each other between nodes with nodes other displays dense regions.

The yellow color accompanying some topics indicates the saturation level of the many issues that often appear. These colors include theory, article, study, analysis, context. In other words, these topics are often researched. Simultaneously, the issues accompanied by green color include gender, impact,

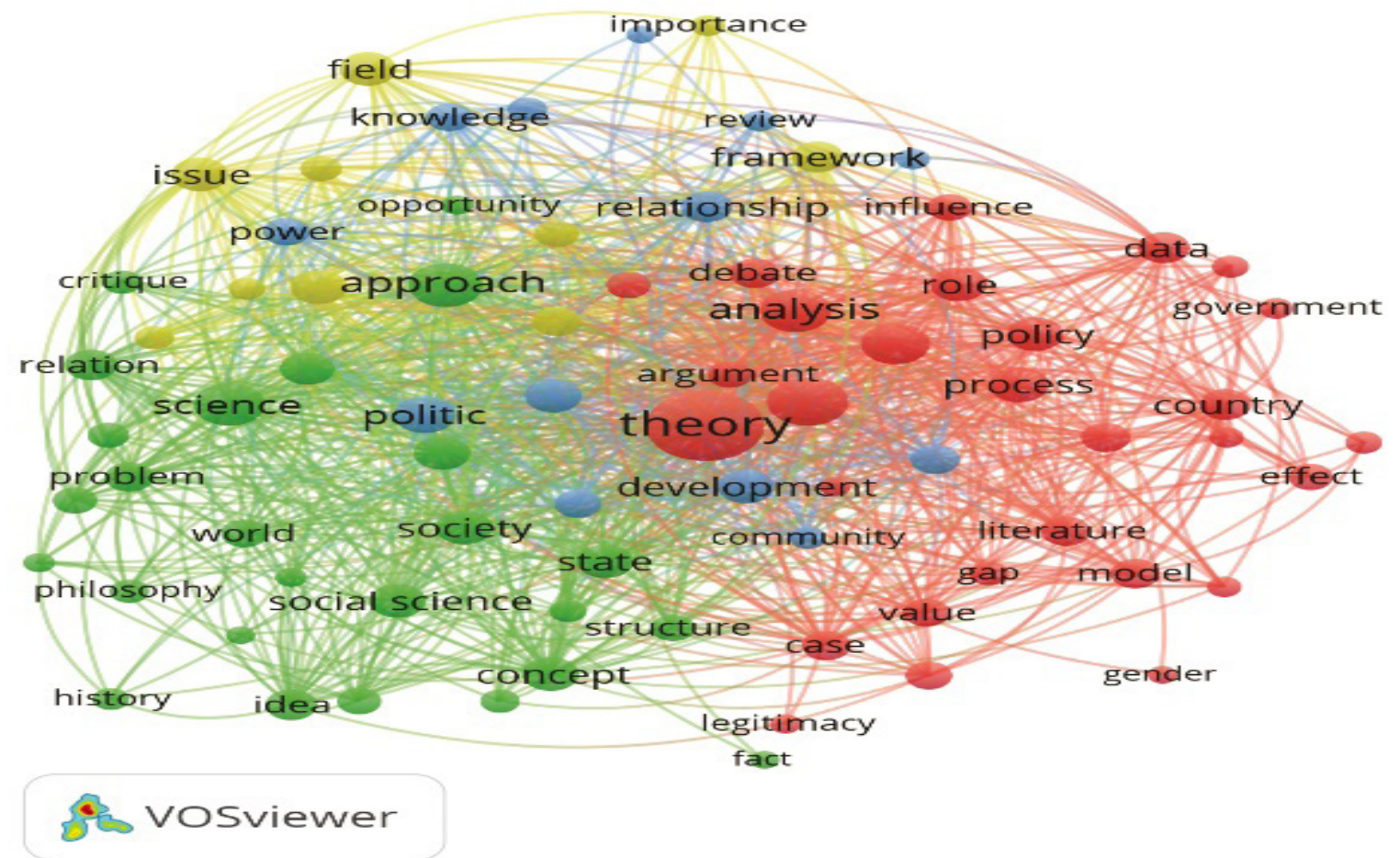

Source: by Author use VOSViewer

Figure 9. Network visualization of 230 documents on a political theory published in 2016-2020 based on titles and abstracts. 


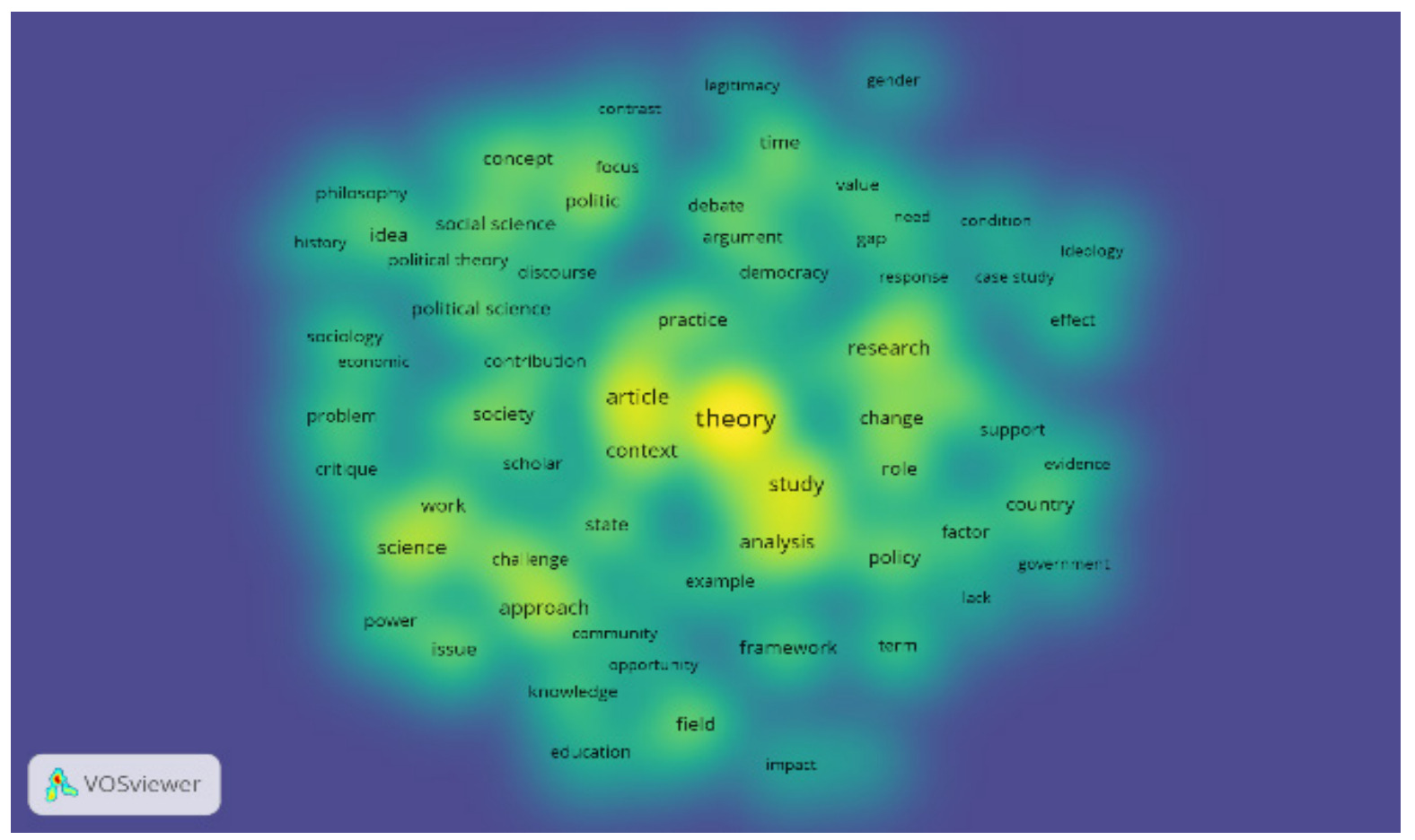

Source: by Author use VOSViewer

Figure 10. Visualization density from 230 dokumen about the theory of political science in 2016-2020

ideology, education, and legitimacy. These topics have not been thoroughly studied in the 2016-2020 period. This indicates t research gap in the "theory of political science" so that the opportunity to research topics accompanied by green is still extensive.

\section{Categorization, Relationship, Mapping Themes Categorization of Themes}

To analyze the categorization between themes in 230 documents of "theory of political science" from 2016 to 2020, sourced from the Scopus database (www.scopus.com). Researchers used NVivo 12 Plus software. Figure 10 shows ten main topics in the "theory of political science" from 2016 to 2020: political, theory, social, sciences, studies, research, approach, analysis, policy, and public.

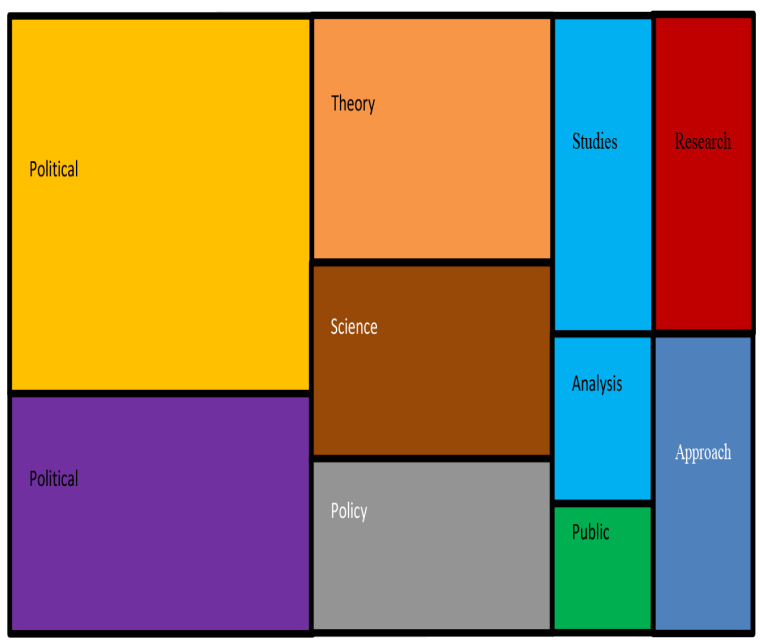

Source: by Author use NVivo 12 Plus

Figure 11. Categorization of Themes
From the categorization of themes processed with the Auto Code feature on the NVivo 12 Plus software with a choice of identification themes, ten political theme categorizations emerged. This theme is the most studied by previous researchers, namely, theory, social, science, study, approach, analysis, policy, public. Furthermore, each of these themes is further divided into several indicators.

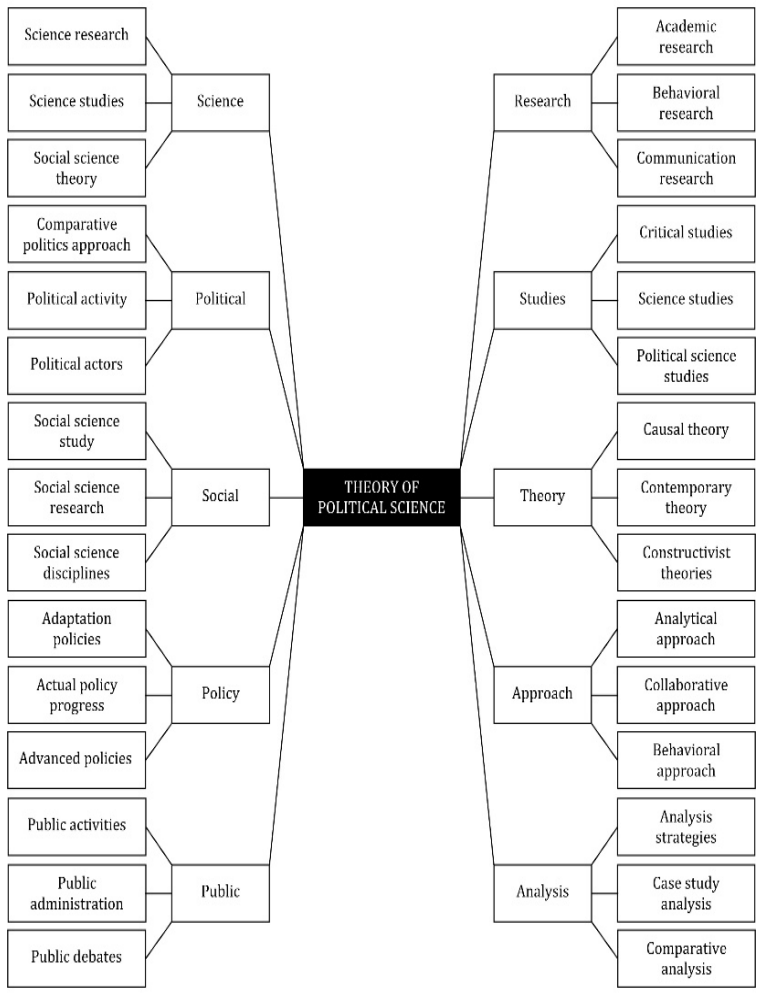

Source: by Author use NVivo 12 Plus

Figure 12. The formulation of the political theory model 
In Figure 12. Above, it can be seen that the development of research on the theory of political science has a comprehensive, complex, and interrelated scope. Also, because political science cannot be separated from humans, it is interesting to care about political science. The three sub-topics of each topic in figure 12 above are the ones that have the highest score in the analysis based on the feature Auto Code of the NVivo 12 Plus software for 230 documents indexed by Scopus (www.scopus.com).

\section{Linkages Between Themes}

A study using NVivo Plus 12 also shows a definite relationship between "theory of political science" with the topics of theory, politics, science, studies, research, approach, analysis, policy, public (table 9). The coefficient of jacquard itself is used to measure correlation (Wang et al., 2013). Jaccard coefficient or correlation coefficient to calculate the similarity between sample sets. This metric is often used to measure similarity to compare chemical compounds (Cao, Jiang, and Girke 2010)and cannot handle today's large compound databases with several million entries. Results: In this article, we introduce a new algorithm for accelerated similarity searching and clustering of very large compound sets using embedding and indexing (EI. The Jaccard coefficient can also be found in various fields, such as searching for similarities via the web, detecting similar documents (Murugesan et al. 2010), and network analysis. Although this relationship has different Jaccard coefficient values, the policy themes and the other nine themes confirm that this study cannot be separated from the topics of theory, political, science, studies, research, approach, analysis, policy, and public. The relations and coefficient values between themes can be seen in Figure 13 and Table 9.

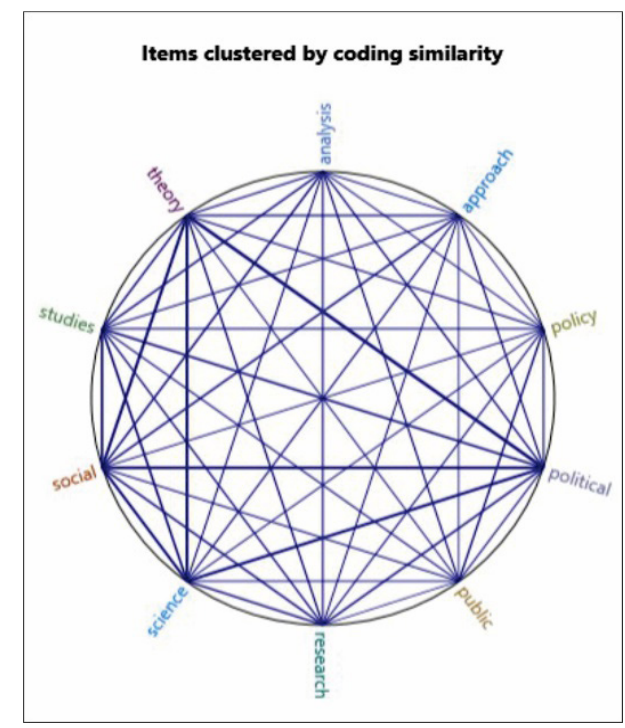

Source: by Author use NVivo 12 Plus

Figure 13. The relationship between themes calculated by Jaccard's coefficient
Table 9. List of Jaccard coefficient values from the theme theory against nine other themes

\begin{tabular}{|l|l|r|}
\hline \multicolumn{1}{|c|}{ Code A } & \multicolumn{1}{c|}{ Code B } & Jaccard's Coefficient \\
\hline Theory & Political & 0.678733 \\
\hline Theory & Social & 0.587379 \\
\hline Theory & Science & 0.56 \\
\hline Theory & Studies & 0.40099 \\
\hline Theory & Research & 0.384615 \\
\hline Theory & Approach & 0.37234 \\
\hline Theory & Analysis & 0.338542 \\
\hline Theory & Policy & 0.333333 \\
\hline Theory & Public & 0.294737 \\
\hline
\end{tabular}

Source: by Author use NVivo 12 Plus

\section{Dominant Topics in the Map of Research Development}

Based on the analysis of Word Frequency queries using NVivo 12 Plus software on 230 research documents indexed by Scopus to explore the words that appear most frequently in the development of research on "Political Theory" from 2016 to 2020, the most dominant and strongly related words/topics in these documents are theory, political, science, studies, research, approach, analysis, policy, public. For more details, the most dominant research topic on the "theory of political science" can be seen in Table 10.

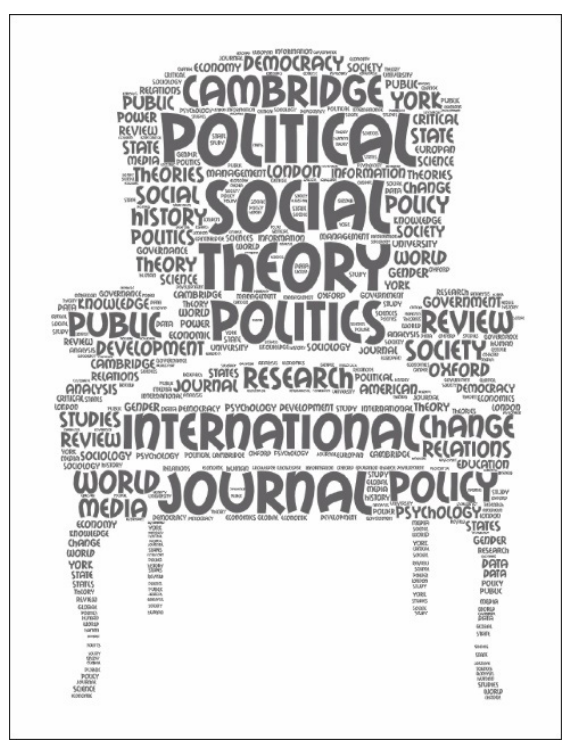

Source: by Author use NVivo 12 Plus

Figure 14. The dominant topic in research "theory of political science."

Table 10. List of dominant topics

\begin{tabular}{ccc}
\hline Word & Length & Count \\
\hline university & 10 & 2683 \\
political & 9 & 2644 \\
social & 6 & 2251 \\
science & 7 & 1811 \\
journal & 7 & 1675 \\
theory & 6 & 1523 \\
politics & 8 & 1366 \\
international & 13 & 1326 \\
Cambridge & 9 & 1246 \\
policy & 6 & 1170 \\
york & 4 & 1113 \\
London & 6 & 1094 \\
studies & 7 & 1032 \\
\hline
\end{tabular}




\begin{tabular}{cll}
\hline research & 8 & 984 \\
oxford & 6 & 893 \\
review & 6 & 837 \\
public & 6 & 815 \\
change & 6 & 721 \\
society & 7 & 716 \\
American & 8 & 693 \\
\hline
\end{tabular}

Source : by Author use NVivo 12 Plus

Table 10 displays the value of each word visualized from 230 Scopus indexed documents that have the format of.RIS in the last five years (20162020). From the 50 made-up stories, the writer took the 20 words that had the most significant frequency and their relationship with the development of research on political science theory. Table10 above shows that the word university is the most outstanding value with 2683 , followed by political with 2644 . It is followed by other words such as social, science, journal theory, politics, and international political science theory in 2016-2020.

\section{DISCUSSION}

The validity of the findings is narrowed by the weakness of the keyword-based intrinsic bibliometric analysis. The author's research with explicit operationalization and equally restrictive political theory research has resulted in some works on political theory. Furthermore, this research concentrates on published academic studies, with outputs produced by nonprofit organizations, non-governmental organizations, government departments, and think tanks. Despite these methodological limitations, there are clear patterns and movements in the data that relate to others, thus lending some exciting ideas. Few political theory types of research in different international journals explicitly discuss theoretical investigations.

Furthermore, several types of research place their investigations in the context of modern theoretical arguments and the implications or intentional theoretical contributions. The lack of political theory is not new in other fields of study; however, it is prevalent in other related disciplines of science and technology, such as information technology, information systems security, internet use, energy, and water sector studies. This is because the related theoretical study of political theory is a necessary applied component of studying science and technology and places it more complex.

\section{CONCLUSION}

Based on the results of the discussion, the following conclusions can be drawn.

1. The development research for the 2015-2020 period are publications in 2019 .

2. The journal that published the most political theory research articles is the British Journal of Sociology, 15 documents.

3. The most productive institutions/ affiliates that publish political theory research is the University of Oxford

4. The most productive country in publishing political theory research articles is England, name and the most types of research during the 2015-2020 period were articles. 80 Documents

In addition, this study also discusses political theory, which includes 4 clusters and has seven main topics. Furthermore, it can be seen that there are 78 concepts from 230 articles obtained from the Scopus database. The results of the review with VOSviewer show that there are six cluster concepts, namely, cluster one, the related concepts are theory, influence, legitimacy, ideology, cluster 2, which emphasizes the concept of approach, concept, social science, society Cluster 3 is related to the concept of community democracy power, practice cluster 4, Framework, political theory, contribution. In addition, the dominant themes of previous researchers are grouped into ten main categories: Political, theory, science, policy, studies, analysis, public, research, approach. Finally, lima topics have a strong relationship with political theory: Political, social, studies, research, approach, analysis, public policy. Therefore, this research contributes to mapping political theory studies that overview the dominant topics being discussed. The limitation of this research is that the articles reviewed are only sourced from the Scopus database, so they do not have comparative data. Therefore, further research needs to use a comparative analysis approach involving the Scopus database and the Web of Sciences (WoS).

\section{REFERENCES}

Aribowo, Eric Kunto. 2019a. “Analisis Bibliometrik Berkala Ilmiah Names: Journal of Onomastics Dan Peluang Riset Onomastik Di Indonesia." Aksara 31(1): 91-111. https://www.erickunto. com/wp-content/uploads/2020/03/373-15631-PB.pdf.

2019b. Membangun Science Mapping
Menggunakan VOSviewer. Indonesia:
Youtube. https://www.youtube.com/
watch?v=Zukkn3Z6u6U\&feature=youtu.be.
Bailusy, Muh Kausar. 2015. "Otoritas Ilmuan Sosial
Politik , Dalam Dinamika Politik." The
POLITICS: Jurnal Magister Ilmu Politik
Universitas Hasanuddin 1(2): 191-202.
https://journal.unhas.ac.id/index.php/politics/
article/view/247/pdf.


Cao, Yiqun, Tao Jiang, and Thomas Girke. 2010. "Accelerated Similarity Searching and Clustering of Large Compound Sets by Geometric Embedding and Locality Sensitive Hashing." Bioinformatics 26(7): 953-59. https://doi.org/10.1093/bioinformatics/btq067.

Craig, John. 2020. "The Emergence of Politics as a Taught Discipline at Universities in the United Kingdom." British Journal of Politics and International Relations 22(2): 145-63. https:// doi.org/10.1177/1369148119873081.

Eck, Nees Jan Van, andLudo Waltman. 2014. Measuring Scholarly Impact Measuring Scholarly Impact.

- 2016. "Text Mining and Visualization." Text Mining and Visualization: 1-5.

van Eck, Nees Jan, Ludo Waltman, Rommert Dekker, and Jan van den Berg. 2010. "A Comparison of two techniques for Bibliometric Mapping: Multidimensional Scaling and VOS Nees." Journal of the American Society for Information Science and Technology 61(December): 2405-16. http://onlinelibrary. wiley.com/doi/10.1002/asi.22883/abstract.

Hakim, Lukmanul. 2020. "Analisis Bibliometrik Penelitian Inkubator Bisnis Pada Publikasi Ilmiah Terindeks Scopus." Jurnal Ilmiah Manajemen e-ISSN 8(2): 176-89.

Haryanti, Amelia, and Yulita Pujilestari. 2019. Bandung: Sinar Baru Algesindo Sistem Politik Indonesia. 1st ed. ed. Ichwan Siti Utami. Tangerang Selatan: UNPAM PRESS.

Hood, Christopher, Desmond King, and Gillian Peele. 2014. Forging a Discipline: A Critical Assessment of Oxford's Development of the Study of Politics and International Relations in Comparative Perspective. 1st ed. Oxford: Oxford University Press.

Ibraín Enrique Corrales-Reyes, Juan José ReyesPérez, Yasmany Fornaris-Cedeño. 2016. "Bibliometric Analysis of the J Oral Res. Period 2012-2015." Journal of Oral Research 5(5): 188-93. http://www.joralres.com/index. php/JOR/article/view/249/240.

Jain, Swati, et al. 2015. "Bibliometric Analysis of Journal of Clinical and Diagnostic Research (Dentistry Section; 2007-2014)." Journal of Clinical and Diagnostic Research 9(4): 47-51.

Krauskopf, Erwin. 2018. "A Bibliometric Analysis of the Journal of Infection and Public Health: 2008-2016." Journal of Infection and Public Health 11(2): 224-29. http://dx.doi. org/10.1016/j.jiph.2017.12.011.
Murugesan, Mummoorthy, et al. 2010. "Efficient Privacy-Preserving Similar Document Detection." VLDB Journal 19(4): 457-75. https://doi.org/10.1007/s00778-009-0175-9.

Nur, Muhammad. 2014. "Rekonstruksi Epistemologi Politik: Dari Humanistik Ke Profetik." AsySyir'ah Jurnal Ilmu Syari'ah dan Hukum 48(1): $131-60$.

Panda, Ispita, Bulu Maharana, and Durlav Charan Chhatar. 2013. "The Journal of Information Literacy: A Bibliometric Study.” International Journal of Scientific and Research Publications 3(3): 603-9.http://citeseerx.ist.psu.edu/viewdoc/ d?doi=10.1.1.416.4304\&rep=rep1\&type $=$ pdf\# page $=604$.

Perianes-Rodriguez, Antonio, Ludo Waltman, and Nees Jan van Eck. 2016. "Constructing Bibliometric Networks: A Comparison between Full and Fractional Counting." Journal of Informetrics 10(4): 1178-95. http:// dx.doi.org/10.1016/j.joi.2016.10.006.

Raab, Charles D. 2012. "FIFTY YEARS AND MORE: THE DEPARTMENT OF POLITICS AT THE Charles D. Raab." http://www.pol.ed.ac.uk/_data/assets/pdf file/0008/91466/Politics_Dept_History.pdf.

Restrepo, Guillermo, and Peter Willett. 2017. "The Journal of Mathematical Chemistry: A Bibliometric Profile." Journal of Mathematical Chemistry 55(8): 1589-96. https://doi.org/10.1007/s10910-017-0747-7.

Roskin, Michael G. 2020. "Political Science." Encyclopedia Britannica, Inc. https://www. britannica.com/topic/political-science (January 21, 2021).

Saleh, Abdul Rahman, and Erni Sumarni. 2016. "Studi Bibliometrik Pada Jurnal Standardisasi Pasca Terakreditasi (2011 - 2015)." Visi Pustaka 18(Desember): 231-40.

Sari, Milya. 2020. "Penelitian Kepustakaan (Library Research) Dalam Penelitian Pendidikan IPA." Natural Science: Jurnal Penelitian Bidang IPA dan Pendidikan IPA 6(1): 41-53. https:/ejournal.uinib.ac.id/jurnal/index.php/ naturalscience/article/view/1555/1159.

Sitepu, P.Anthonius. 2012. Teori-Teori Politik. Edisi 1; C. Yogyakarta: Graha Ilmu.

Syafiie, Inu Kencana. 2017. Ilmu Pemerintahan. Cetakan ke. ed. Suryani. Jakarta: PT. Bumi Aksara.

Waltman, Ludo, Nees Jan van Eck, and Ed C.M. Noyons. 2010. "A Unified Approach to 
Mapping and Clustering of Bibliometric Networks." Journal of Informetrics 4(4): 629-35. joi.2010.07.002.

Wang, Shuai, Haoliang Qi, Leilei Kong, and Cuixia Nu. 2013. "Combination of VSM and Jaccard Coefficient for External Plagiarism Detection." Proceedings - International Conference on Machine Learning and Cybernetics 4: 1880-85. https://doi. org/10.1109/ICMLC.2013.6890902.
Wicaksono, MV, DH Agustiani, EE Artika, and Yolanda Adellia. 2020. "Menelaah Budaya Literasi Tokoh-Tokoh Bersejarah Di Indonesia." Tibandaru: Jurnal Ilmu Perpustakaan dan Informasi 4: 70-86. https:// journal.uwks.ac.id/index.php/Tibandaru/ article/view/938/pdf.

Winarno, Budi. 2013. "Ilmu Sosial Dan Ilmu Politik: Filsafat, Teori Dan Metodologi." Jurnal Upnyk 17(1): 1-20. 